\title{
Correction to: Henry Kissinger's Three Europes
}

\section{Mario Del Pero ${ }^{1}$}

Published online: 5 March 2019

(C) The Editor of the Journal 2019

\section{Correction to: Journal of Transatlantic Studies https://doi.org/10.1057/s42738-019-00004-2}

The article Henry Kissinger's Three Europes, written by Mario Del Pero, was originally published electronically on the publisher's internet portal (currently SpringerLink) on 18 February 2019 with open access.

With the author(s)' decision to step back from Open Choice, the copyright of the article changed on 4 March 2019 to $(\odot)$ The Editor of the Journal 2019 and the article is forthwith distributed under the terms of copyright.

The original article has been corrected.

Publisher's Note Springer Nature remains neutral with regard to jurisdictional claims in published maps and institutional affiliations.

The original article can be found online at https://doi.org/10.1057/s42738-019-00004-2.

\section{Mario Del Pero}

mario.delpero@sciencespo.fr

1 Department d'Histoire, SciencesPo, 27 Rue Saint-Guillaume, 75007 Paris, France

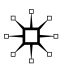

